\title{
Relevance of the Annual National Program for NATO Accession - Case of Bosnia and Herzegovina
}

\section{Značaj Godišnjeg nacionalnog programa za pristupanje u NATO - Slučaj Bosne i Hercegovine}

\author{
Alija Kožljak \\ alija.kozljak@ibu.edu.ba \\ Haris Šehović \\ haris.sehovic@ibu.edu.ba
}

\begin{abstract}
NATO integration processes have been constantly a complex topic for the public to grasp, in particular in the case of Bosnia and Herzegovina. Several confronting efforts were constantly in place, which often created confusion and slowed down the progress. To explain the problem, the research question has been set as: "How relevant is ANP for the NATO Accession?" The objective is to examine what the ANP as a document stands for, and how does it assist or hinder the aspiring states on their NATO path. The relevance for examination of this question lies in the fact that most political actors within Bosnia and Herzegovina use the lack of knowledge of the public on the topic to promote their agenda or present themselves as the defenders of the narrow interest of their ethnic group. To provide the society with accurate analysis, this research will examine if ANP will assist Bosnia and Herzegovina on its NATO accession path. Data will be collected using qualitative research methods and secondary research.
\end{abstract}

Sažetak: NATO integracijski proces je uvijek bio složena tema za shvatanje javnosti, naročito u slučaju Bosne $i$ Hercegovine. Nekoliko suprotstavljenih napora su stalno djelovali, što je često uzrokovalo zbunjenost $i$ usporenje napretka. Da se problem objasni, sljedeće istraživačko pitanje je postavljeno: „Koliko je ANP relevantan za pristupanje NATO-u?" Cilj je ispitati za šta ANP kao dokument stoji te kako pomaže ili odmaže državama koje se nadaju učlanjenju. Relevantnost za ispitivanje ovog pitanja leži u činjenici da većina političkih aktera u BiH koriste nedostatak znanja javnosti da promovišu vlastite agende ili da se pokažu kao branioci uskih interesa vlastite etničke grupe. Sa ciljem da se javnosti pruži tačna analiza, ovo istraživanje ispituje da li ANP pomaže BiH na svom putu NATO integracija. Podaci su skupljeni koristeći kvalitativne istraživačke metode i sekundarno istraživanje.
Keywords: accession, ANP, Bosnia and Herzegovina, MAP, NATO

JEL Classification: F51

Article History

Submitted: 21/12/2021

Accepted: 31/12/2021

Ključne riječi: pristupanje, ANP, Bosna i Hercegovina, $M A P, N A T O$

Historija članka

Dostavljen: 21.12.2021

Prihvaćen: 31.12.2021 


\section{INTRODUCTION}

The enlargement process of NATO is still in place, which has been proved by the clear stance of the member states to keep the 'Open-door policy resolutely groomed (US State Department, 2021). After granting the membership to most of the eastern European states as well as to the four former Yugoslav republics, only Bosnia and Herzegovina and Serbia (plus Kosovo), remained out of the Alliance's umbrella. Currently, there are three nations, which have expressed their willingness to join NATO: Bosnia and Herzegovina (BiH), Georgia, and Ukraine (North Atlantic Treaty Organization, 2020). BiH is the only aspirant country from the Western Balkans region and is currently considered to be the entry point to NATO membership. That has been even officially confirmed by the fact that Bosnia and Herzegovina is the only aspirant that has submitted its Annual National Program, thus activating the Membership Action Plan (MAP), the key pre-accession instrument of the Alliance (North Atlantic Treaty Organization, 2020).

BiH officially received an invitation to join the Membership Action Plan (MAP) in 2010, during the NATO Ministerial meeting in Tallinn, when the Alliance set a precondition for the activation of the MAP, which refers to the registration of the prospective immovable defense property to the state level. This precondition was set predominantly to test the functioning of the state-level institutions (North Atlantic Treaty Organization, 2010). That could be also linked to one of the NATO membership criteria, more specifically, the functioning of the democratic political system. Although Bosnia and Herzegovina made tangible progress in some areas, specifically defense and armed forces, security, and humanitarian demining, activation of the MAP did not happen until 2019, mostly due to the reluctance of politicians from the BiH entity of Republika Srpska to fulfill the Tallinn precondition (North Atlantic Treaty Organization, 2010). However, registration of 30 out of 63 locations, underpinned with participation in international operations and adoption of the defense review document, used to be major arguments to reinterpret the Tallin precondition (North Atlantic Treaty Organization, 2010). Finally, the Alliance accepted all this as tangible progress, thus NATO ministers decided in December 2018 to extend an invitation to $\mathrm{BiH}$ to submit its first Annual National Program (ANP) document. Another year has been spent debating the submission of the ANP to Brussels. President of the leading political party from the Republika Srpska Milorad Dodik created another political deadlock, questioning the continuation of the NATO integration process. That kind of acting was evidently against the law, in particular the BiH Law on Defense from 2005 and its article 84, which clearly states: "The Parliamentary Assembly, the Council of Ministers, the Presidency and all subjects of defense within their own constitutional and legal jurisdiction, will carry out the necessary activities for the accession of Bosnia and Herzegovina to NATO membership" (BiH Defense Law, 2005).

A year later, with the assistance of the international community, the members of the Presidency of Bosnia and Herzegovina reached an agreement to submit the first ANP, renaming the document to the "Program of Reforms of Bosnia and Herzegovina" (Ministry of Foreign Affairs $\mathrm{BiH}, 2021)$.

This paper is based on a conventional literature review, which has collected the academic sources, policy documents, and official records, related to the NATO integration process, focusing on the major tool the ANP. The objective was to integrate the key components and analytically assess the substance of the literature content and identify primary study disparities. This study is structured through six chapters, including an introduction part that provides a general background for the topic. Every one of the major chapters elaborates key components of the analysis, corresponding with the relevant literature. Consequently, the second chapter 
evaluates the Activation of MAP for Bosnia and Herzegovina; the third analysis outlined reforms, examining completion of activities; the fourth part reviews obstacles for the implementation of the Program of Reforms of Bosnia and Herzegovina, specifically examining administrative, legal, and practical obstacles; the fifth paragraph analysis the implementation impacts on the accession.

A few databases are utilized for classifying books, journals, documents, and newspapers, including the Research Gate, Google Scholar, and MoD and MFA Archives. With a limited application of filters, the research literature is focused on the sources that are mainly considered NATO integration tools. The open academic literature is very general, however official documents and reports offer sufficient data, relevant for this study. The essential technique for coding is based on the theoretic background of the literature selected, which facilitated an adequate data collection and analysis, applying the qualitative analysis methods and comparative document analysis. This topic is significant because of the identified deficiency of the research related to the efficiency of the NATO integration mechanisms and tools. Before all, this absence implies the issue of the competence of the Annual National Program and MAP for the aspirant countries' efforts to overcome obstacles, fulfill required preconditions, and accomplish reforms. The intent is to make, a contribution in improving the evaluation of the NATO integration tools, as well as in expanding the overall understanding of their relevance and significance. Thus, the full paper is composed of an introductory part, five main chapters, a conclusion part, 10 tables. and the literature section.

\section{ACTIVATION OF MAP FOR BOSNIA AND HERZEGOVINA}

By submitting its first ANP, after 10 years of delay, NATO activated Membership Action Plan (MAP) for Bosnia and Herzegovina, which is the key instrument of advice and assistance, tailormade to the needs of each state that seeks to join in the Alliance (North Atlantic Treaty Organization, 2020). It is important to highlight that participation in MAP does not prejudge the NATO membership, however, it certainly assists an aspirant in preparing for the membership. This suggests that productive participation in the MAP process is not a sufficient prerequisite for membership, so it could last for years since political consensus is also needed to begin the accession process.

An illustrative example could be made by the case of North Macedonia, which spent twenty years participating in the MAP. This country fulfilled all preconditions to join the Alliance, however, its historical disagreements with Greece over the name of the country, prevented the completion of the integration process (Papadimas, 2019). This demonstrates a political aspect of the accession process when the decision-making process has been driven by the interest of the NATO member state. Article 10 of the Washington Treaty guaranteed that all member states need to unanimously agree on accepting new members. Greece used this blockade as leverage to fulfill its national interest, influencing the government in Skopje to change the name of the country (Papadimas, 2019).

As it has been seen from the arguments presented above, the MAP is activated once the aspiring state sends its first ANP to the NATO HQ. Bearing in mind that Bosnia and Herzegovina submitted the document under a different name, it caused some confusion regarding the activation of the MAP. One of the reasons why the renaming of the document created confusion within the Bosnian public was the lack of knowledge and information. However, after comparing the document with any ANP previously submitted, it is clear that the same structure has been applied, as well as the methodology of completing the paper (Government of Croatia, 2003). NATO member states also clearly confirmed the relevance of the document, which 
helped with the following activities (U.S. State Department, 2021). Thus, the ANP is a document that is made out of numerous tables, as the Program of Reform. In those tables are outlined chapters and areas in which an aspiring state needs to conduct its reforms. The areas cover Political, Military, Defense, Resource, Security, and Legal aspects (North Atlantic Treaty Organization, 2020). The aspiring state fills out these tables and sends them over to NATO HQ every year for evaluation. Hence, by submitting ANP an aspirant country participates in the MAP.

\section{ANALYSIS OF OUTLINED REFORMS}

As it was previously stated, the Membership Action Plan has been created to assist aspirant countries to prepare for membership in the Alliance. We will apply a comparative analysis of the two Program of Reforms of Bosnia and Herzegovina documents, in order two examine the level of implementation of reforms. Activities outlined in an Annual National Program directly correspond with the reforms required in respective areas. Accordingly, the progress will be measured by evaluating the completion of activities listed in all six major areas, which are specified by the structure of the document. Consequently, if we compare the respective elements of two annual documents, we could realize the level of the progress made between two submissions, which shows the adequacy of the ANP as an accession tool. The following tables are extracts from the two official Programs of reforms of Bosnia and Herzegovina documents.

\begin{tabular}{|c|c|c|c|c|}
\hline \multicolumn{4}{|c|}{ 1. POLITICAL AND ECONOMIC ISSUES } & \multirow[b]{3}{*}{ Remarks } \\
\hline 1.1. & \multicolumn{3}{|c|}{ FOREIGN AND SECURITY POLICY } & \\
\hline 1.1.1. & RELATIONS WITH NATO & $\begin{array}{l}\text { Responsible } \\
\text { Authority }\end{array}$ & Timeline & \\
\hline Goal 1.1.1.1. & $\begin{array}{c}\text { Engage in dialogue and practical } \\
\text { cooperation with NATO }\end{array}$ & & & \\
\hline Activity 1 & $\begin{array}{l}\text { Continuation of registration of } \\
\text { AFBIH prospective defense sites }\end{array}$ & $\begin{array}{l}\text { Relevant } \mathrm{BiH} \\
\text { political } \\
\text { institutions and } \\
\text { bodies }\end{array}$ & $2019-2020$ & $\begin{array}{l}\text { NATO } \\
\text { assistance } \\
\text { required }\end{array}$ \\
\hline Activity 2 & $\begin{array}{l}\text { Engage in dialogue with NATO } \\
\text { regarding regional and Euro- } \\
\text { Atlantic security challenges }\end{array}$ & $\begin{array}{l}\text { Relevant } \mathrm{BiH} \\
\text { political } \\
\text { institutions and } \\
\text { bodies }\end{array}$ & $2019-2020$ & $\begin{array}{l}\text { NATO } \\
\text { assistance } \\
\text { required }\end{array}$ \\
\hline Activity 3 & Implement the PfP SOFA & $\begin{array}{l}\text { Relevant } \mathrm{BiH} \\
\text { political } \\
\text { institutions and } \\
\text { bodies }\end{array}$ & $2019-2020$ & $\begin{array}{l}\text { NATO } \\
\text { assistance } \\
\text { required }\end{array}$ \\
\hline
\end{tabular}

Table 1 (Ministry of Foreign Affairs BiH. 2019)

\begin{tabular}{|c|l|l|l|l|l|}
\hline 1. & 2. & \multicolumn{3}{|c|}{ POLITICAL AND ECONOMIC ISSUES } \\
\hline 1.1. & \multicolumn{3}{|c|}{ Foreign and Security Policy } \\
\hline 1.1.1. & Relations with NATO & $\begin{array}{l}\text { Responsible } \\
\text { institution }\end{array}$ & $\begin{array}{c}\text { Cooperation } \\
\text { with }\end{array}$ & Timeframe & Remarks \\
\hline Goal 1.1.1.1. & $\begin{array}{l}\text { Participation in dialogue and } \\
\text { practical cooperation w/ } \\
\text { NATO }\end{array}$ & & & & \\
\hline
\end{tabular}




\begin{tabular}{|c|l|c|c|c|c|}
\hline Activity1 & $\begin{array}{l}\text { Participation in dialogue with } \\
\text { NATO on regional and Euro- } \\
\text { Atlantic security challenges }\end{array}$ & MFA BIH & $\begin{array}{c}\text { Relevant } \\
\text { BiH } \\
\text { institutions } \\
\text { and bodies }\end{array}$ & $\begin{array}{c}\text { During } \\
2021 .\end{array}$ & $\begin{array}{c}\text { NATO } \\
\text { assistance } \\
\text { needed }\end{array}$ \\
\hline Activity 2 & Implementation PfP SOFA & MFA BIH & $\begin{array}{c}\text { Relevant } \\
\text { BiH } \\
\text { institutions }\end{array}$ & $\begin{array}{c}\text { During } \\
2021 .\end{array}$ & $\begin{array}{c}\text { NATO } \\
\text { assistance } \\
\text { needed }\end{array}$ \\
\hline Activity 3 & $\begin{array}{l}\text { Fully utilize all available PfP } \\
\text { instruments of cooperation }\end{array}$ & MFA BIH & $\begin{array}{c}\text { Relevant } \\
\text { BiH } \\
\text { institutions }\end{array}$ & $\begin{array}{c}\text { During } \\
2021 .\end{array}$ & $\begin{array}{c}\text { NATO } \\
\text { assistance } \\
\text { needed }\end{array}$ \\
\hline
\end{tabular}

Table 2 (Ministry of Foreign Affairs BiH. 2021)

Compering the first set of tables in the Program of Reforms document (2019-2020) as well as the 2021 version, it is visible that relations with NATO are highlighted under the Foreign and Security Policy. The registration of immovable defense property (Mitrović, 2020), as the most important reform and precondition set before Bosnia and Herzegovina by NATO, is written in the 2019-2020 version of the document. However. it has been excluded from 2021, which suggests that there are serious obstacles in completing this activity. This could be explained as an outcome of continuous disruptive political efforts in Bosnia and Herzegovina.

\begin{tabular}{|c|l|c|c|c|c|}
\hline 1.1.3. & \multicolumn{1}{|c|}{$\begin{array}{c}\text { RELATIONS WITH } \\
\text { NEIGHBORS }\end{array}$} & $\begin{array}{c}\text { Responsible } \\
\text { institution }\end{array}$ & $\begin{array}{c}\text { Cooperation } \\
\text { with }\end{array}$ & Timeframe & Remarks \\
\hline $\begin{array}{c}\text { Activity } \\
1\end{array}$ & $\begin{array}{l}\text { Develop good neighborly } \\
\text { relations, } \\
\text { cooperation, and regional } \\
\text { cooperation }\end{array}$ & MFA BIH & & $\begin{array}{c}\text { During } \\
2021 .\end{array}$ & \\
\hline $\begin{array}{c}\text { Activity } \\
2\end{array}$ & $\begin{array}{l}\text { Improve } \\
\text { economical, political, and } \\
\text { security cooperation }\end{array}$ & MFA BIH & & $\begin{array}{c}\text { During } \\
2021 .\end{array}$ & \\
\hline
\end{tabular}

Table 3 (Ministry of Foreign Affairs BiH. 2021)

\begin{tabular}{|c|c|c|c|c|}
\hline 1.1.3. & $\begin{array}{c}\text { RELATIONS WITH } \\
\text { NEIGHBOURS }\end{array}$ & $\begin{array}{c}\text { Responsible } \\
\text { Authority }\end{array}$ & Timeline & Remarks \\
\hline Activity 1 & $\begin{array}{c}\text { Develop relations focusing on Euro- } \\
\text { Atlantic processes, good neighborly } \\
\text { relations, economic cooperation, } \\
\text { and strengthening regional } \\
\text { cooperation }\end{array}$ & MFA & $2019-2020$ & MFA \\
\hline Activity 2 & $\begin{array}{c}\text { Improve economic, cultural, } \\
\text { political, and security cooperation }\end{array}$ & $2019-2020$ & \\
\hline
\end{tabular}

Table 4 (Ministry of Foreign Affairs BiH. 2019)

Relations with neighbors' chapter is relevant due to traditional connections among countries, in particular, because of the constant influence from Serbia and Croatia towards Bosnia and Herzegovina, which is often malign. Croatia declaratively supports the Euro-Atlantic progress of Bosnia and Herzegovina and the strengthening of regional cooperation, but its diplomatic activities and statements often indicate destabilization of the progress of the country. The President of Croatia even publicly warned $\mathrm{BiH}$ authorities that Croatia will block the E-A integration process (Mrkić, 2020) if the Election law will not be changed as Bosnian HDZ 
(Croats Democratic Party) required. Serbia is constantly supporting destructive activities from the Republika Srpska entity, which directly affects the E-A integration process. The two outlined activities in the tables above remained the same in both versions of the document which is an indicator that there has not been specific progress made in achieving those goals. Hence, the evidence shows a consta, from inside, but also outside of the country, which additionally complicates implementation political obstruction of activities.

\begin{tabular}{|c|c|c|c|c|}
\hline 1.1 .8 & $\begin{array}{c}\text { ARMS CONTROL AND } \\
\text { MILITARY } \\
\text { EQUIPMENT } \\
\end{array}$ & $\begin{array}{l}\text { Responsible } \\
\text { Authority }\end{array}$ & Timeline & Remark \\
\hline Goal 1.1.8.1 & $\begin{array}{l}\text { Implementation of the } \\
\text { SALW Strategy and } \\
\text { Roadmap for Sustainable } \\
\text { Solution to the Illegal } \\
\text { Possession, Misuse, and } \\
\text { Trafficking of SALW and } \\
\text { their Ammunition in the } \\
\text { WB }\end{array}$ & & & \\
\hline Activity 1 & $\begin{array}{l}\text { Raise public awareness } \\
\text { concerning the negative } \\
\text { effects of the use of SALW }\end{array}$ & $\begin{array}{l}\text { MoS/CB/Pol } \\
\text { ice Agencies }\end{array}$ & Continuous & \\
\hline Activity 2 & $\begin{array}{l}\text { Implement the SALW } \\
\text { collection project }\end{array}$ & $\begin{array}{l}\text { MoS/CB/Pol } \\
\text { ice Agencies }\end{array}$ & Continuous & NATO Assistance Required \\
\hline Activity 3 & $\begin{array}{l}\text { Develop capacities for the } \\
\text { destruction of surplus } \\
\text { weapons and unstable } \\
\text { ammunition }\end{array}$ & MoD & Continuous & NATO Assistance Required \\
\hline
\end{tabular}

Table 5 (Ministry of Foreign Affairs BiH. 2019)

\begin{tabular}{|c|c|c|c|c|c|}
\hline 1.1.8. & $\begin{array}{l}\text { ARMS CONTROL AND } \\
\text { MILITARY EQUIPMENT }\end{array}$ & $\begin{array}{c}\text { Responsible } \\
\text { institution }\end{array}$ & $\begin{array}{l}\text { Cooperation } \\
\text { with }\end{array}$ & Timeframe & Remarks \\
\hline $\begin{array}{c}\text { Goal } \\
1.1 .8 .1\end{array}$ & $\begin{array}{l}\text { Implementation of SALW } \\
\text { strategy and Roadmap for a } \\
\text { sustainable solution of illegal } \\
\text { possession, misuse, and trade } \\
\text { of SALW in the Western } \\
\text { Balkans }\end{array}$ & & & & \\
\hline $\begin{array}{c}\text { Activity } \\
1\end{array}$ & $\begin{array}{l}\text { Organizing campaigns on } \\
\text { raising awareness, in } \\
\text { cooperation with } \mathrm{BiH} \\
\text { institutions and international } \\
\text { organizations }\end{array}$ & more & $\begin{array}{c}\mathrm{KO} / \\
\text { Police } \\
\text { agencies/UINO }\end{array}$ & Continuous & \\
\hline $\begin{array}{c}\text { Activity } \\
2\end{array}$ & $\begin{array}{l}\text { Organize at least two } \\
\text { destructions of SALW }\end{array}$ & more & $\begin{array}{c}\mathrm{KO} / \text { Police } \\
\text { agencies/UINO }\end{array}$ & Continuous & $\begin{array}{l}\text { NATO } \\
\text { assistance } \\
\text { needed }\end{array}$ \\
\hline $\begin{array}{l}\text { Activity } \\
3\end{array}$ & $\begin{array}{l}\text { Develop capacities for the } \\
\text { destruction of SALW and } \\
\text { unstable ammunition }\end{array}$ & MoD & & $\begin{array}{l}\text { During } \\
2021 .\end{array}$ & $\begin{array}{c}\text { In } \\
\text { cooperation } \\
\text { with NATO }\end{array}$ \\
\hline
\end{tabular}

Table 6 (Ministry of Foreign Affairs BiH. 2021)

Arms control and military equipment chapter of the document will be analyzed by comparing two activities:

1) Reduce the number of SALW and unstable illegal ammunition by organizing their destruction. The aim is to make $\mathrm{BiH}$ society more safe and secure, but also to harmonize the procedures with NATO and EU standards. 
2) Establishing a state-level register of movement of weapons and military equipment, which gives a more complete oversight over military equipment and improves safety measures.

As with the previous table, the activities in this chapter remained the same, except activity number 2. In the 2019-2020 version of the Reforms Program document, activity number 2 is defined as the implementation of the SALW collection project. The collection project is a continuous activity in which citizens of Bosnia and Herzegovina who own SALW can voluntarily return/deposit them at a few locations around the country to relevant authorities, without legal repercussions (SEESAC, 2014). In the latter table from the 2021 version of the document, activity number 2 is defined as the organization of destruction of SALW. This indicates that the activity of collection SALW was completed in the 2019-2020 period and 2021 will be used for its destruction. In practice, implementation of these activities in large part depends on the budget of the responsible institutions (in this case MoD, MoS, police agencies), which also depends on the support of the governing political parties.

\begin{tabular}{|c|c|c|c|c|c|}
\hline 1.2.11. & $\begin{array}{l}\text { DEMOCRATIC CONTROL AND } \\
\text { OVERSIGHT OVER OSA }\end{array}$ & $\begin{array}{l}\text { Responsible } \\
\text { institution }\end{array}$ & $\begin{array}{l}\text { Cooperation } \\
\text { with }\end{array}$ & Timeframe & Remarks \\
\hline $\begin{array}{c}\text { Goal } \\
1.2 .11 .1 .\end{array}$ & $\begin{array}{l}\text { Ensure proper oversight and control } \\
\text { over Intelligence agency through } \\
\text { lawful work, methods, and } \\
\text { management, financial planning, and } \\
\text { spending, operations in line with } \\
\text { human rights Convention }\end{array}$ & & & & \\
\hline $\begin{array}{c}\text { Activity } \\
1\end{array}$ & $\begin{array}{l}\text { Evaluate reports submitted by the } \\
\text { director, general inspector of OSA as } \\
\text { well as the president of the Council of } \\
\text { Ministers }\end{array}$ & $\begin{array}{c}\text { Joint } \\
\text { Commission } \\
\text { on OSA }\end{array}$ & & $\begin{array}{l}\text { During } \\
2021 .\end{array}$ & \\
\hline $\begin{array}{l}\text { Activity } \\
2\end{array}$ & $\begin{array}{l}\text { Evaluate complaints of citizens, } \\
\text { agency employees, and relevant } \\
\text { media articles on the agency }\end{array}$ & $\begin{array}{l}\text { Joint } \\
\text { Commission } \\
\text { on OSA }\end{array}$ & & During2021. & \\
\hline $\begin{array}{c}\text { Activity } \\
3\end{array}$ & $\begin{array}{l}\text { Conduct oversight visits to the } \\
\text { agency and its field offices }\end{array}$ & $\begin{array}{c}\text { Joint } \\
\text { Commission } \\
\text { on OSA } \\
\end{array}$ & & $\begin{array}{l}\text { During } \\
2021 \text {. }\end{array}$ & \\
\hline $\begin{array}{c}\text { Activity } \\
4\end{array}$ & $\begin{array}{l}\text { Hold meetings with public } \\
\text { administration bodies that cooperate } \\
\text { with the agency }\end{array}$ & $\begin{array}{c}\text { Joint } \\
\text { Commission } \\
\text { on OSA } \\
\end{array}$ & & $\begin{array}{l}\text { During } \\
2021 .\end{array}$ & \\
\hline $\begin{array}{l}\text { Activity } \\
5\end{array}$ & $\begin{array}{l}\text { Conduct investigations or hearings in } \\
\text { front of the commission }\end{array}$ & $\begin{array}{c}\text { Joint } \\
\text { Commission } \\
\text { on OSA } \\
\end{array}$ & & & \\
\hline $\begin{array}{c}\text { Activity } \\
6\end{array}$ & $\begin{array}{l}\text { Analyze audit reports on execution of } \\
\text { the budget }\end{array}$ & $\begin{array}{l}\text { Joint } \\
\text { Commission } \\
\text { on OSA }\end{array}$ & & $\begin{array}{l}\text { During } \\
2021 .\end{array}$ & \\
\hline
\end{tabular}

Table 7 (Ministry of Foreign Affairs BiH. 2021)

\begin{tabular}{|c|c|c|c|c|}
\hline Goal 1.2.12.1. & $\begin{array}{c}\text { Ensure appropriate oversight and } \\
\text { control of the work of the BiH } \\
\text { Intelligence Security Agency } \\
\text { through the legality of work, } \\
\text { method of work and management, } \\
\text { financial planning and spending, } \\
\text { operations in line with the Human } \\
\text { Rights Convention }\end{array}$ & Responsible \\
Authority & Timeline & Remarks & & \\
\hline Activity 1 & $\begin{array}{c}\text { Consider regular and special reports } \\
\text { submitted to the committee by OSA } \\
\text { Director, Inspector General, and } \\
\text { Chair of CoM }\end{array}$ & JCOSA & $2019-2020$ & \\
\hline
\end{tabular}




\begin{tabular}{|c|c|c|c|}
\hline Activity 2 & $\begin{array}{l}\text { Consider appeals by citizens, } \\
\text { complaints by employees, and } \\
\text { relevant media reports on the work } \\
\text { of OSA }\end{array}$ & JCOSA & $2019-2020$ \\
\hline Activity 3 & $\begin{array}{c}\text { Conduct supervisory visits to OSA } \\
\text { HQ and field offices }\end{array}$ & JCOSA & $2019-2020$ \\
\hline Activity 4 & $\begin{array}{l}\text { Hold meetings with other public } \\
\text { administration bodies cooperating } \\
\text { with OSA }\end{array}$ & JCOSA & $2019-2020$ \\
\hline Activity 5 & $\begin{array}{c}\text { Conduct investigations or hearings } \\
\text { before the committee }\end{array}$ & JCOSA & $2019-2020$ \\
\hline Activity 6 & $\begin{array}{l}\text { Analyze audit reports on the } \\
\text { executions of the budget }\end{array}$ & JCOSA & 2019-2020 \\
\hline
\end{tabular}

Table 8 (Ministry of Foreign Affairs BiH. 2019)

Two chapters presented in the Tables 7 and 8 are referred to the activities and reforms in the Intelligence-Security Agency (OSA) and the Armed Forces of Bosnia and Herzegovina $(\mathrm{AFBiH})$. In the chapter on Intelligence-Security Agency of $\mathrm{BiH}$, activities range from establishing proper democratic oversight control over the Agency to the analysis of audit reports on the executions of the budget.

Both tables hold the same activities to be conducted, however, all the activities planned by the Joint Commission on OSA in $\mathrm{BiH}$ Parliament, ranging from Activity 2-7, have not been conducted at all. Evidence shows, the commission does not hold any sessions due to the political blockades and it is safe to assume that the outlined activities in the table will also find themselves outlined in the next Program of Reforms document. The Oversight Committee work is important because it makes sure that OSA does not overstep its competencies in its activities and violate the rights of $\mathrm{BiH}$ citizens.

\begin{tabular}{|c|c|c|c|c|c|}
\hline 1.2 .12 & $\begin{array}{l}\text { DEMOCRATIC CONTROL AND } \\
\text { OVERSIGHT OF ARMED FORCES } \\
\text { BIH }\end{array}$ & $\begin{array}{l}\text { Responsible } \\
\text { institution }\end{array}$ & $\begin{array}{c}\text { Cooperation } \\
\text { with }\end{array}$ & Timeframe & Remarks \\
\hline $\begin{array}{c}\text { Goal } \\
1.2 .11 .1 .\end{array}$ & $\begin{array}{l}\text { Ensure democratic control and } \\
\text { oversight over AFBIH by Joint } \\
\text { Committee }\end{array}$ & & & & \\
\hline $\begin{array}{c}\text { Activity } \\
1\end{array}$ & $\begin{array}{l}\text { Oversee the activities of } \\
\text { implementation and update of } \\
\text { Security policies and Defense } \\
\text { policies of } \mathrm{BiH}\end{array}$ & $\begin{array}{c}\text { Joint } \\
\text { Committee } \\
\text { on Defense } \\
\text { and Security }\end{array}$ & & $\begin{array}{c}\text { During } \\
2021 .\end{array}$ & \\
\hline $\begin{array}{c}\text { Activity } \\
2\end{array}$ & $\begin{array}{l}\text { Oversight over the defense budget } \\
\text { and solving problems in the process } \\
\text { of public procurement }\end{array}$ & $\begin{array}{c}\text { Joint } \\
\text { Committee } \\
\text { on Defense } \\
\text { and Security }\end{array}$ & & $\begin{array}{c}\text { During } \\
2021 .\end{array}$ & \\
\hline $\begin{array}{c}\text { Activity } \\
3\end{array}$ & $\begin{array}{l}\text { Oversight of activities with regards to } \\
\text { registration of movable and } \\
\text { immovable defense property }\end{array}$ & $\begin{array}{l}\text { Joint } \\
\text { Committee } \\
\text { on Defense } \\
\text { and Security }\end{array}$ & & $\begin{array}{c}\text { During } \\
2021 .\end{array}$ & \\
\hline $\begin{array}{c}\text { Activity } \\
4\end{array}$ & $\begin{array}{l}\text { Conduct visits and start discussions } \\
\text { with MoD representatives, Joint staff, } \\
\text { Operational Command, and units of } \\
\text { AFBIH }\end{array}$ & $\begin{array}{c}\text { Joint } \\
\text { Committee } \\
\text { on Defense } \\
\text { and Security }\end{array}$ & & $\begin{array}{c}\text { During } \\
2021 .\end{array}$ & \\
\hline
\end{tabular}

Table 9 (Ministry of Foreign Affairs BiH. 2021) 


\begin{tabular}{|c|c|c|c|c|}
\hline Goal 1.2.11.1. & $\begin{array}{c}\text { Ensuring democratic control and } \\
\text { oversight of the AFBIH by the } \\
\text { BiH PA JCDS }\end{array}$ & $\begin{array}{c}\text { Responsible } \\
\text { Authority }\end{array}$ & Timeline & Remarks \\
\hline Activity 1 & $\begin{array}{c}\text { Monitor activities in the } \\
\text { implementation, update, and } \\
\text { amendments to the BiH Security } \\
\text { Policy and Defense Policy }\end{array}$ & $\begin{array}{c}\text { Joint } \\
\text { Committee on } \\
\text { Defense and } \\
\text { Security (JCDS) }\end{array}$ & $2019-2020$ & \\
\hline Activity 2 & $\begin{array}{l}\text { Oversight of the defense budget } \\
\text { and resolution of problems in the } \\
\text { process of public procurement }\end{array}$ & JCDS & $2019-2020$ & \\
\hline Activity 3 & $\begin{array}{l}\text { Monitor activities related to the } \\
\text { resolution of the issue of } \\
\text { immovable defense property }\end{array}$ & JCDS & $2019-2020$ & \\
\hline Activity 4 & $\begin{array}{l}\text { Conduct visits and discussions } \\
\text { with BiH MoD, Joint Staff, } \\
\text { Operational Command, and } \\
\text { AFBIH units' representatives }\end{array}$ & JCDS & $2019-2020$ & \\
\hline
\end{tabular}

Table 10 (Ministry of Foreign Affairs BiH. 2019)

The oversight of the Armed Forces of $\mathrm{BiH}$ (Tables 9 and 10) is a constant process to comply with democratic values is the task supposed to be implemented by the Joint Committee on Defense and Security (JCDS). The outlined activities in these tables also highlight some of the issues with the implementation of the Program of Reforms BiH. Activity number 2 in both documents deals with overseeing the defense budget and solving problems with public procurement. Thus, due to the budget reduction, the Ministry of Defense was not able to fully complete its activities (Čengić, 2020). A positive signal was the adoption of the Defense Review, which defines the structure, size, and capacity of $\mathrm{AFBiH}$, as well as the development and modernization of armed forces, however, budget restrictions prevented adequate implementation of this important strategic document (US Embassy in Bosnia and Herzegovina, 2016). The modernization of the AFBiH has been partly possible with the help of friendly states. For instance, the US-supported acquisition of the four Bell Huey II helicopters (BiH Ministry of Defense, 2021). Also, the EU donated equipment for the demining battalion, as well as Turkey armored vehicles. The process of public procurement is always under public scrutiny in all government institutions.

As far as Activity number 3 is concerned, monitoring the resolution of immovable defense property issue, all activities in this regard have been halted because of the political crisis in Bosnia and Herzegovina which is presented as a blockade of state institutions. Only 32 locations have been registered to the state level. As far as Activity number 4 is concerned, visits to the Joint Staff, MoD, and Operational Command are an already established practice and continue routinely, which reveals that this activity has been implemented.

\section{OBSTACLES FOR IMPLEMENTATION OF PROGRAM OF REFORMS}

As outlined above, the reluctance towards the NATO integration has been present, which was confirmed by the hesitation of the politicians from the entity of RS to submit the first ANP document to Brussels, hence, to activate the Membership Action Plan. This however was not the first time that politicians of the entity of Republika Srpska attempted to prevent the NATO path of BiH. Ever since the Tallinn conference in 2010, there has been a persistent, systematic effort to undermine the $\mathrm{BiH}$ progress towards NATO accession. These efforts can be categorized as legal and administrative, political, and practical. 
Several arguments provide evidence that the Dayton Constitution sets severe constraints for the competent functioning of state-level institutions. That has been particularly sustained by the setting that granted transfer of sovereignty from the state to the entity and canton levels. In such circumstances, the efficiency of state-level institutions has been undermined, enabling entities to place obstructions for state-level initiatives, which includes implementation of the strategic policies, like participation in the MAP, certainly is.

The complex administrative structure of the country additionally complicates the efficiency of the state government since 14 different parliaments exist in such a small country. More than a hundred ministries function at a different level of governing, creating their agendas, which are not coordinated well (Mijatović, 2020). This is not a friendly environment for the sufficient implementation of the state priorities and plans.

The complicated decision-making process has been a direct consequence of such intricate administrative and legal settings, which makes it harder to reach a consensus about important strategic issues. Therefore, the response is often late, as well as inadequate. An example of that is the renaming of the Commission for the NATO Integration Process of Bosnia and Herzegovina to The Commission for cooperation with NATO; (North Atlantic Treaty Organization, 2021) or renaming of the Annual National Program to the Program of Reforms of Bosnia and Herzegovina, where consensus did not include just change of the name, but also reduction of the activities, initially proposed in the draft version of the document.

The legal basis for the accession lies in Article 84 of the Law on Defence from 2005, as well as the Presidency decision from 2005, which was reached via consensus. These legal realities balance previously elaborated administrative obstacles to stop the entire process.

\section{Political obstacles}

Political obstacles cannot be sufficiently analyzed isolated from legal and administrative, due to the obvious mutuality and interdependence. However, some political issues will be highlighted, just for a better illustration of the problem. Governing political parties in Bosnia and Herzegovina, although acting as a coalition, do not have any common political platform, or operational agenda, therefore, their work and activities are usually based on the confronting standing positions. Their politics are often ethnically centered, thus it is very difficult to reach a compromise in such confronting conditions. Therefore, some political actors misuse ethnic background to discuss NATO topics with emotions instead of arguments, hence imposing unfriendly perceptions towards NATO integrations in advance. There is strong evidence of the external political influence, mainly from Russian Federation and Serbia that, pursuing their national interests, oppose the NATO enlargement process to the Western Balkans. "BiH has fallen victim to the Russian-Serbian agreement which is supported by a certain part of Croatian and Bosniak politicians in BiH" (Ifimes, 2013). Consequently, their proxies, mostly politicians from the Republika Srpska entity often block the progress of Bosnia and Herzegovina towards NATO. 


\section{Practical obstacles}

The practical obstacles use to be a direct consequence of the malign political behavior of politicians, which has been enabled by legal and administrative settings. As an outcome, it inspires the downgrading of the coordination efforts of state institutions on the intended activities. Thus, in such circumstances, it is not difficult to block the registration of the prospective immovable defense property to the state level. Also, it is not surprising to witness constant disputes about a sufficient defense budget. Consequently, the lack of completion of activities outlined in the Program of Reforms document stands to be a clear example of practical obstacles to implementing the Annual National Program (Program of Reforms).

\section{IMPLEMENTATION IMPACTS ON THE ACCESSION}

As stated above, many attempts of blockades were attempted within the $\mathrm{BiH}$ institutions, which remains a serious issue, related to the adoption of the Program of Reforms. Parliament of the Republika Srpska entity adopted the decision on military neutrality, to undermine the NATO integration process (Kovačević, 2017). Although this decision is meaningless, being aware that security and defense-related matters are within the competencies of the state, creates confusion amongst the $\mathrm{BiH}$ population and NATO allies. This creates a noticeable negative effect on the accession efforts of Bosnia and Herzegovina, which suggests that international assistance is needed to unblock the processes and push for reforms.

Implementation of the Program of Reforms document directly correlates with the progress of the country towards NATO integration. The level of realization in every outlined area is presented by the percentage of implementation, which includes the evaluation of every specific activity. Consequently, that has been linked with concrete implications. For example, the reforms of the Armed Forces of BiH will increase the interoperability with NATO member states' forces and will increase their combat readiness for peace support operations abroad. Additionally, some reform activities from the document are also in line with the 2018 European Commission Opinion on Bosnia and Herzegovina (European Commission, 2019) for instance, activities related to human rights. This suggests that implementation of the Program of Reforms will also affect the European Union integration process. This could also lead to fundamental changes in the Constitution of Bosnia and Herzegovina, considering its discriminatory elements towards certain populations of $\mathrm{BiH}$.

\section{CONCLUSION}

Activation of Membership Action Plan enables an aspirant country to utilize its Annual National Program as an instrument to enhance the reform process. The document is structured in a way to evaluate progress in all major areas, relevant to the NATO membership. This study indicates that the Program of Reforms of Bosnia and Herzegovina is structured exactly as an ANP, applying the same methodology. Therefore, it enables Bosnia and Herzegovina to exploit the advantages of the MAP in its full capacity. The more detailed the activities in each key area are presented, the more precise and accurate the evaluation of progress is made. The degree of implementation of respective activities directly illustrates the progress of the country. A low level of implementation directly indicates where the assistance is needed, which detects the areas where further efforts should be arranged. Therefore, Annual National Program seems to be a relevant instrument to assist the country in accomplishing reforms and preparing it for the accession process. However, due to the strong impact of national interests and political factors, 
the case of Bosnia and Herzegovina shows that successful implementation of ANP does not necessarily assure membership to NATO.

\section{REFERENCES}

Maxwell \& Olsen. (2013). Destination NATO: Defense Reform in Bosnia and Herzegovina 2003-2013. RUSI. https://jfcnaples.nato.int/systems/file_download.ashx?pg=1442\&ver=3

Johnston. S. (2017). How NATO Adapts: Strategy and Organization in the Atlantic Alliance since 1950. John Hopkins University Press.

Mulchinock. N. (2017). NATO and the Western Balkans: From Neutral Spectator to Proactive Peacemaker. Palgrave MacMillan.

Croatian Annual National Program. Government of Croatia. (2003). Retrieved from https://vlada.gov.hr/UserDocsImages//2016/Sjednice/Arhiva//10.\%20-\%203.pdf

Law on Defense. (2005). Ministry of Defense. Retrieved from http://www.mod.gov.ba/files/file/zakoni/Zakon-o-odbrani-bs.pdf

Ministry of Foreign Affairs BiH. (2019). Program of Reforms 2019. Retrieved in hard copy from Ministry of Foreign Affairs BiH.

Ministry of Foreign Affairs BiH. (2021). Program Reformi Bosne i Hercegovine 2021. eKonsultacije. Retrieved: https://ekonsultacije.gov.ba/legislativeactivities/details/110879

Ifimes. (2013). BiH: NATO rejects Bosnia and Herzegovina due to Russia's influence. https://www.ifimes.org/en/researches/bih-nato-rejects-bosnia-and-herzegovina-due-to-russiasinfluence/3507?fbclid=IwAR3MHq2XrlFqX39yz_LQJ3m2R8--Mt5Odb_xwPR_sRE6T6NwfivQ1yti3Y

MoD. (2021). Novi helikopteri OS BiH se pripremaju za primopredaju. Ministry of Defense. http://www.mod.gov.ba/aktuelnosti/vijesti/?id=89074

North Atlantic Treaty Organization. (2010, March 10). NATO Foreign Ministers Meeting in Tallinn. NATO. Retrieved December 6, 2021, from https://www.nato.int/cps/en/natolive/news_62121.htm?mode=pressrelease

North Atlantic Treaty Organization. (2014). The Tallinn Precondition. NATO. Retrieved from https://www.nato.int/cps/fr/natohq/opinions_108059.htm?selectedLocale=en

North Atlantic Treaty Organization. (2020, May 5). NATO Enlargement. NATO. Retrieved December 6, 2021, from https://www.nato.int/cps/en/natolive/topics_49212.htm

North Atlantic Treaty Organization. (2020, March 23). Membership Action Plan. NATO.

Retrieved from https://www.nato.int/cps/en/natolive/topics_37356.htm

North Atlantic Treaty Organization. (2021). Relations with Bosnia and Herzegovina. NATO. Retrieved from https://www.nato.int/cps/en/natohq/topics_49127.htm 
EESAC. (2014, August 4). SEESAC Supports the SALW Collection Campaign in Bosnia and Herzegovina. Seesac.Org. https://www.seesac.org/News_1/SEESAC-Supports-the-SALWCollection-Campaign-in-Bosnia-and-Herzegovina/

U.S. State Department. (2021, August 27). U.S. Relations With Bosnia and Herzegovina. United States Department of State. https://www.state.gov/u-s-relations-with-bosnia-and-herzegovina/

I. E. U. S. Sarajevo. (2016). Defense Review Decision. U.S. Embassy in Bosnia and Herzegovina. Retrieved from https://ba.usembassy.gov/defense-review-decision/

European Commission. (2019). European Commission Opinion on BiH. Retrieved from https://ec.europa.eu/commission/presscorner/detail/de/COUNTRY_19_2778

Kozljak, A. (2020). Deadlock in Bosnia and Herzegovina-extensive political and security consequences. Retrieved from

https://www.researchgate.net/publication/344450506_Deadlock_in_Bosnia_and_Herzegovina _-_extensive_political_and_security_consequences

Čengić. A. (2020, June 18). Podžić: Neću glasati za budžet, jer u njemu nisu predviđena sredstva za izbore. Retrieved from Avaz.ba. https://avaz.ba/vijesti/bih/576648/podzic-necu-glasati-zabudzet-jer-u-njemu-nisu-predvidena-sredstva-za-izbore

Mrkić. G. (2020, October 2). Prijeti li Hrvatska blokadom NATO puta BiH. Retrieved from Avaz.ba. $\quad$ https://avaz.ba/vijesti/bih/599283/prijeti-li-hrvatska-blokadom-nato-putabih?fb_comment_id=3328989143821106_3329000273819993

Mitrović. S. (2020). NATO put BiH: Knjiženje vojne imovine i dalje problem. N1. Retrieved from https://ba.n1info.com/vijesti/a436775-nato-put-bih-knjizenje-vojne-imovine-i-daljeproblem/

Kovačević. D. (2018, May 18). Bosnian Serbs Adopt Resolution on Military Neutrality. Retrieved from Balkan Insight. https://balkaninsight.com/2017/10/18/bosnian-serb-entityadopted-the-resolution-on-military-neutrality-10-18-

2017/?fbclid=IwAR3PF5uRGF6yQK0Wn2cdFpmDa6otTUwGdupjAtd5o8RN4jz_olC3FuW XOL4

Mijatović. D. (2020). The Dayton Accords could only do so much. Retrieved from DW.COM. https://www.dw.com/en/opinion-the-dayton-accords-could-only-do-so-much/a-55938718

Papadimas, L. G. G. (2019, February 9). After years of stalling, Greece oks Macedonia in NATO. Reuters. https://www.reuters.com/article/us-greece-macedonia-natoidUSKCN1PX27Z 